NBER WORKING PAPER SERIES

TAXATION OF FOREIGN-OWNED LAND

James A. Brander

Working Paper No. 3070

NATIONAL BUREAU OF ECONOMIC RESEARCH

1050 Massachusetts Avenue

Cambridge, MA 02138

August 1989

I thank Murray Frank, David Nickerson, and Barbara Spencer for helpful comments. Financial support from the Donner Foundation and from the Centre for International Business Studies at the University of British Columbia is gratefully acknowledged. This paper is part of NBER's research programs in Taxation and International Studies. Any opinions expressed are those of the author not those of the National Bureau of Economic Research. 
NBER Working Paper \#3070

August 1989

\title{
TAXATION OF FOREIGN-OWNED LAND
}

\section{ABSTRACT}

This paper examines the welfare effects of a tax on foreign purchases of domestic land. Using a simple static framework the paper shows that an appropriately chosen tax will generally be welfare-improving for the domestic country.

\author{
James A. Brander \\ Faculty of Commerce and Business \\ Administration \\ University of British Columbia \\ Vancouver, B.C. V6T IY8 \\ Canada
}




\section{Introduction}

In several major cities in the U.S. and Canada, such as Los Angeles, San Francisco, and Vancouver, the rapid growth of foreign real estate ownership has become a significant political issue. Various policy responses have been suggested, including investment controls and special taxes on foreign purchases of domestic real estate. My objective in this paper is to examine whether taxes on foreign land investment are likely to raise or lower national welfare.

As observed by Ricardo (1817), land is essentially a fixed asset: increases in land investment do not (normally) increase the quantity of land. ${ }^{1}$ It is therefore less than obvious that unrestricted foreign investment in domestic land is welfare-maximizing for the domestic economy. A very interesting recent paper by Jonathan Eaton (1988) examines foreign investment in land using an overlapping generations model of the Peter Diamond (1965) type. Eaton focuses on the dynamic interaction between the portfolio and production aspects of foreign investment in land, and identifies circumstances in which a general land tax may be welfare-improving.

While the effects analyzed by Eaton (1988) are of dear significance, there is a simpler and perhaps even more fundamental rationale for intervention in the land investment process. Specifically, it seems dear that each domestic country has some market power with respect to its own land. A small increase in the price of domestic land would not reduce foreign land investment to zero. However, the domestic land market itself is very competitive. Therefore, in the absence of government intervention, the domestic economy will fail to extract the maximum return from its land. In other words, just as the combination of country-level market power with competitive firm-level behaviour creates a rationale for a "monopoly tariff" on traded goods (as in Harry Johnson (1953)), there is a similar rationale for a tax on foreign land investment. The selection of an optimal tax on foreign investment in land requires balancing the revenue effects of an increase

\footnotetext{
${ }^{1}$ St rictly speating, of courae, it may be pousible to expand the zopply of asable land by draining swamps and other methods. One might argee, on the otber had, that any act of land improvement (such $=$ draining swampland) i really a captial investment and fietinct from the "raf" land. I any case, it im important to distinguish between asests that are esentially fixed and those that we agmentable. Taking land as a fixed aset reems a reasonable first approximation.
} 
in the tax against any benefits or costs arising fom increasing the ownership share of domestic investors. This tradeoff arises even in a purely static context, and certainly carries over to a dynamic en vironment.

Section 2 makes this point in the simplest possible model, in which land is a pure consumption good. Section 3 extends the analysis to the more quantitatively important case of land used as a productive input. Section 4 discusses extensions and contains some concluding remarks.

\section{Vacation Land}

This section presents the argument for price discrimination in land in its simplest and purest form. It also makes transparent the parallel between a land investment tax and a monopoly tariff. The model is static (although it has a dynamic counterpart in which all values represent present discounted values and agents either iive forever or have a dynastic bequest motive), and abstracts from various issues related to production and portfolio decisions. It should become clear, however, that the basic point identified in this section is robust to various extensions and generalizations.

The assumptions of this case correspond to what might be described as "vacation land": domestically owned land yields a flow of services to domestic residents, while foreign owned land yields a flow of services to foreigners. Once purchased by foreigners, this "vacation land" is used " exclusively by its owners, who do not otherwise interact with the domestic economy. This is equivalent to the assumption that owners of land are able to appropriate all net value deriving from it. ${ }^{2}$

There is a fixed supply of land, $L^{0}$. Domestically owned land is denoted $L$ and foreign-owned land is denoted $L^{*}$. Thus

$$
L+L^{*}=L^{0}
$$

There is a representative domestic agent with ntility $U=v(L)+m$, where $m$ is consumption of a

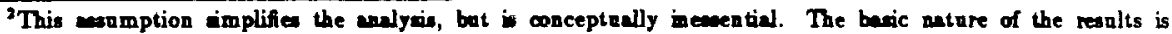
unchanged $\boldsymbol{a}$ long $\boldsymbol{a}$ the omere of the had apropriate come portion of whtever vilue it generates.
} 
numeraire good. The representative foreign investor has utility $U^{*}=u^{*}\left(L^{*}\right)+m^{*}$. If land is sold to foreign investors, it is sold at price $q^{*}$. Domestic residents therefore have two sources of welfare associated with land: they can consume the services of land or they can sell land to foreigners and consume more of the numeraire good. If domestic land is sold to foreigners, then domestic residents will import an amount of the numeraire good equal to land sales revenue. The revenue raised from land sales is denoted $R\left(L^{*}\right)$.

$$
R\left(L^{*}\right)=q^{*} L^{*}
$$

Assuming that all land is domestically owned to begin with, domestic welfare, $U$, from this land resource can be written as follows.

$$
U(L)=u(L)+R\left(L^{*}\right)
$$

Maximizing domestic welfare subject to constraint (1) yields the following furst arder condition. ${ }^{3}$

$$
u^{\prime}(L)+R^{\prime}\left(L^{*}\right) d L^{*} / d L=0
$$

Since $d L^{*} / d L=-1$ from (1), first order condition (4) implies

$$
\mathbf{u}^{\prime}(L)=R^{\prime}\left(L^{*}\right)
$$

Condition (5) says that domestic marginal utility from land ownership should be set equal to marginal revenue from land sales. Utility maximization by (competitive) domestic residents implies that the domestic land price, denoted $q$, will be equal to $u^{\prime}(L)$. The marginal revenue from land sales is $q^{*}+L^{*} d q^{*} / d L^{*}$, so equation (5) yields

$$
q=q^{*}+L^{*} d q^{*} / d L^{*}
$$

From (6) we see that domestic welfare maximization requires that the foreign land price exceed the domestic land price if the foreign demand for domestic land is down ward sloping. The optimal

\footnotetext{
'Second order conditions are anmed to be globally atified throughout the peper. This requires standard
assumptions about utility and (in section 3) production functions.
} 
policy can be achieved by placing a tax on foreign land purchases equal to the solution value of $-L^{*} d q^{*} / d L^{*}$, and distributing the tax revenue to domestic consumers.

This basic argument here is similar to the observation made (in a dynamic context) by James Brander and Slobodan Djacic (1983) that a country exporting a nonrenewable resource should price discriminate between domestic and foreign consumers if it is to maximize domestic welfare. Land is like an extreme version of a fixed resource. In fact the model as it stands does not really distinguish between exports of a fixed resource and foreign investment in a fixed asset such as land. This serves to emphasize the point that exports of a fixed resource and sales of a fixed real asset are very similar. In a model with both exports and sales of fixed real assets, imports can be funanced either by exports or by net asset sales to foreigners. Optimal policy involves shifting the terms of this trade in a favorable direction.

\section{Investment and Production}

Most foreign investment in land is related to the value of land as a productive input, rather than to the pure consumption value of land modelled above. In this section I present a very simple model of land investment in production. As before, constraint (1) applies: land may be owned either by domestic residents or by foreign investors. In contrast to section 2 , land is not consumed directly, but is combined with frm specific factors to produce "developed land", which is then consumed. Developed land is denoted $X$.

Total production of developed land, $X$, is simply the sum of developed land produced by domestic and foreign firms. The cotput of domestic firms is $x(L ; k)$ and the output of foreign firms is $x^{*}\left(L^{*}, k^{*}\right)$, where $k$ and $k^{*}$ are factors specific to the domestic and foreign land development industries respectively. All output produced using domestic land is consumed domestically.

$$
X=x(L ; k)+x^{*}\left(L^{*} ; k^{*}\right)
$$

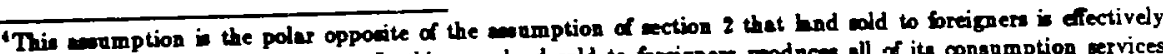
removed from the domeatic economy. In this ase hnd old to freigners produces all of its consumption exvices in the domestic economy.
} 
Prices paid for land by domestic and foreign firms are, as before, $q$ and $q$. The prices may differ because of the possibility of a tax $t$ on foreign land investments: $q=q+t$. Profits for domestic and foreign firms are denoted $\pi$ and $x^{*}$ respectively, and can be written as follows.

$$
\pi(L)=p x(L ; k)-q L \quad ; \quad \pi^{*}\left(L^{*}\right)=p x^{*}\left(L^{*} ; k^{*}\right)-(q+t) L^{*}
$$

The cotcome of foreign land investment will depend in part on the market structure of the land development industry. One possible market structure is that the domestic and foreign sectors consist of price-taking firms that are identical except (possibly) for differences between domestic and foreign firms in firm-specific factors. In this case, treating $L$ and $L^{*}$ as the choice variables, and using subscripts to represent derivatives, profit maximization implies

$$
p x_{L}-q=0 \quad ; \quad p x_{L}^{*}-(q+t)=0
$$

Note that if $t$ is positive, foreign firms can coexist with domestic firms only by operating in a region of their production functions where the marginal product of land is higher than it is in domestic firms. The other extreme is duopoly, in which the domestic and foreign sectors are each represented by a single firm. Under duopoly, first order conditions for profit maximization imply

$$
p \alpha_{L}+v-q=0 ; p x_{L}^{*}+v^{*}-(q+t)=0
$$

where $v=x(d p / d x)^{e} x_{L}$ and $v^{*}=x\left(d p / d x^{*}\right)^{*} x_{L}^{*}$ are the expected effects of an increase in own land use on revenue arising from possible changes in product price. In this case, these terms should presumably reflect the fact that land is a fixed resource and that increases in own land use must therefore imply a decline in land use by the rival firm. In other words, an increase in own cotput should be recognized as reducing the rival's output so that price need not fall as own output rises. Taking this factor into account, these "conjectural" terms should be close to 0 for any market structure. I assume that these terms are zero in what fllows, and therefore that (9C) characterizes the hand development sector. Thus firms act as if they were pure competitors in that land prices are equated to the value of marginal product. Note, however, that there is 
nothing to keep firms in the industry from earning pure profits, which are, in effect, returns to specific factors $k$ and $k^{*}$.

The numeraire good is produced from domestic labor under constant returns to scale and free entry. Thus there are no pure profits from this sector and the wage rate equals the marginal product of labor, which is normalized to be 1 . In addition the numeraire good may be imported.

Domestic utility is given by

$$
U=u(X)+m
$$

All profits earned by domestic firms and revenue from the land tax accrue to domestic residents. Domestic residents are endowed with quantity $m^{0}$ of labor leading to income from labor $m^{0}$, and they own all domestic land. The budget constraint of domestic residents is, therefore:

$$
m^{0}+\pi+q L+(q+t) L^{*}=p X+m
$$

where the left hand side is income and the right band side is expenditures. Subtracting $p X$ from each side of (11), substituting the result in (10), and substituting for domestic profit, $\pi$, from (8) yields the following expression for domestic utility.

$$
U=u(X)-p X+m^{0}+p x+R\left(L^{*}\right)
$$

where $R\left(L^{*}\right)=(q+t) L^{*}$ is revenue from foreign land sales. Product price, $p$, land price $q$, foreignowned land, $L^{*}$, and output $X$ are all infuenced by the foreign land tax, $t$. We can therefore think of domestic welfare as a function of $t$. Differentiating (12) with respect to $t$ and recalling that $u^{\prime}(X)=p$ yields:

$$
d U / d t=-x^{*} p_{t}+p x_{t}+R_{t}
$$

The three terms of equation (13) correspond to the three effects of the land tax. The first term represents a net consnmer surplus effect: any increase in product price reduces consumer surplus at rate $X$, but the domestic firms return $x$ in additional profits to the domestic economy, leaving 
a net cost of $x^{*}$ for each unit increase in price. The second term is a profit-shifting effect. ${ }^{5}$ The final term represents the effect of a tax on revenue from foreign land sales.

The direct effect of an increase in the foreign land tax is to shift land and output from foreign firms to domestic firms, implying that $x_{t}>0$. The effects $p_{t}$ and $R_{t}$ are ambiguous in general. Despite this, it is possible to prove that a small tax on foreign land is better than no tax.

\section{Proposition 1:}

At $t=0$, domestic welfare is increasing in $t$, implying that a small positive tax on foreign investment in domestic land is welfare superior (from the domestic point of view) to a tax of zero. Proof:

$R_{t}$ can be written as $q^{*} L_{t}^{*}+L^{*} q_{t}^{*}$. In addition, $x_{t}=x_{L} L_{t}$ and $L_{t}^{*}=-L_{t}$. Substituting these in (13) yields

$$
d U / d t=-x^{*} p_{t}+\left(p x_{L}-q^{*}\right) L_{t}+L^{*} q_{t}^{*}
$$

At $t=0, q=q^{*}$, so (9C) implies that the middle term of (14) is zero, leaving

$$
d U / d t=-x^{*} p_{t}+L^{*} q_{i}^{*}
$$

The effect of the land investment tax on price, $p_{t}$ can be written as

$$
\begin{aligned}
p_{t} & =p^{\prime}\left(x_{t}+x_{t}^{*}\right) \\
& =p^{\prime}\left(x_{L} L_{t}+x_{L^{*}}^{*} L_{i}^{*}\right) \\
& =p^{\prime} L_{t}\left(x_{L}-x_{L^{*}}^{*}\right)
\end{aligned}
$$

From (9C) at $t=0$ it follows that $x_{L}=x_{L}^{*}$, and therefore that $p_{t}=0$. Finally, $q^{*}>0$ (a tax or foreign owned land must raise the gross foreign price of land), so, assuming that $L^{*}$ is positive, $d U / d t>0$ at $t=0$ as was to be shown.

Provided that the domestic welfare function is globally concave, it follows immediately from Proposition 1 that the optimal policy is to have a positive tax on freign-owned land. The basic

\footnotetext{
See Brander and Barbara Spencer (1981) br an analyois of the peofit-obinting efiects of a tariff.
} 
intuition is that the supply of the asset will not be reduced even if foreign investors are taxed. There is a marginal efficiency cost associated with the tax as outpat is shifted to domestic firms operating in a region of their production functions where the marginal product of land is less than in foreign firms, but this cost is of second arder for small tax levels (and is zero at $t=0$ ). The marginal benefits of the tax may, however, be substantial even at bw tax levels if the foreign demand for domestic assets is relatively melastic.

The model in this section is a good deal less transparent than the model in section 2 , but it probably captures something closer to what most readers regard as the basic nature of foreign land investment. The operative principle is similar in both sections. Specifically, if foreign investors earn rents from their in vestments in domestic land, it will generally be in the national interest to extract some of that rent. This is true whether the foreign rent accrues in the form of consumer surplus or profits or some combination of the two.

\section{Concluding Remarks}

The main result of this paper is that there is a unilateral incentive to extract rent from foreign investors who purchase domestic fixed assets. Only if there are perfect investment substitutes elsewhere will this effect disappear. Since it seems clear that foreign real estate demand is not perfectly elastic, the incentive to impose such taxes appears highly relevant to the current policy debate.

The two related models presented in this paper are simple and stylized. Some of the simplifications are completely inessential. One can easily add additional goods, additional factors, additional fixed assets, a more complex trading environment, a more general utility function, etc. without changing the basic message. One could also combine the models of sections 2 and 3 to treat land as both a consumption good and a productive input. Such extensions require substantial additions to the aigebra, and add a variety of additional complexities such as income effects, complementarities in production among different factors, and cross-substitution effects in 
demand. These complications may, for some parameter values, operate against taxing foreign investment in fixed assets, but they will not remove the basic price discrimination motive described here as long as the domestic country has some market power over its fixed assets.

The more interesting direction of generalization would be to embed the considerations identified here in a dynamic model of the type described by Eaton (1988), where overlapping generations of consumer/investors choose between investments in a fixed asset and an augmentable asset (capital). Such an analysis is beyond the scope of this short paper, but it seems clear that the price discrimination motive will continue to operate, although it may be offset under some circumstances by portfolio and growth considerations that favor foreign investments in fixed assets.

The foreign investment tax examined here is similar to the familiar rent-shifting tariff of international trade theory, and, like the tariff, is vulnerable to the concern that intervention will generate retaliation. It seems very reasonable for most countries to forsake the use of rent-shifting tariffs because they have a lot to gain if other countries do the same. However, the general gains from multilateral agreements to avoid using discriminating foreign investment taxes would seem to be much less symmetrically distributed across countries. After all, the distribution of valuable fixed assets such as land, minerals, etc. is itself highly asymmetric across countries. Furthermore, once dynamic considerations are added to the model, it is far from obvious that general taxation of fixed assets in all countries is welfare-reducing for the world as a whole. It seems likely, therefore, that for many countries, national incentives to use discriminating taxes on foreign investments in fixed assets may be stronger than the incentive to use rent-shifting tariffs. 


\section{References}

Brander, James A. and Slobodan Djajic (1983), "Rent-extracting Tariffs and the Management of Exhaustible Resources", Canadian Journal of Economics 16 (May) 288-298.

Brander, James A. and Barbara Spencer (1981), "Tariffs and the Extraction of Foreign Monopoly Rents Under Potential Entry", Canadian Journal of Economics 14 (August) 371-389.

Diamond, Peter (1965), "National Debt in a Neoclassical Growth Model", American Economic Review 55 (December) 1126-50.

Eaton, Jonathan (1988), "Foteign-Owned Land", American Economic Review 78 (Match) 76-88.

Johnson, Harry (1953), "Optimum Tariffs and Retaliation", Review of Economic Studies 22, 142-153.

Ricardo, David (1817), On the Principles of Political Economy and Taxation, London: John Murray. 